Ewa Gano

Politechnika Poznańska, Polska

TERESA ŁUCZKA

Politechnika Poznańska, Polska

\title{
Determinanty intencji przedsiębiorczych studentów
}

\section{Determinants of Entrepreneurial Intention among University Students}

Streszczenie: Celem badań przedstawionych w artykule jest poznanie predyspozycji i postaw przedsiębiorczych studentów, barier utrudniających im otwieranie własnej działalności gospodarczej oraz czynników motywujących ich do tejże działalności. W artykule wykorzystano wyniki badań własnych przeprowadzonych wśród studentów w wieku 19-25 lat. Badania przeprowadzono za pomocą ankiety audytoryjnej na grupie 540 osób w Wielkopolsce. Przyjęto kryterium płci oraz miejsca zamieszkania respondentów. Pytania dotyczyły predyspozycji przedsiębiorczych, posiadanej przez studentów wiedzy na temat rozpoczynania działalności gospodarczej, barier i czynników zachęcających do aktywności gospodarczej oraz form wspierania przedsiębiorczości oczekiwanych przez studentów. W części empirycznej przedstawiono wyniki badań własnych dotyczących cech charakterologicznych studentów, ich intencji przedsiębiorczych, barier i czynników rozwoju postaw przedsiębiorczych, a także ich potrzeb szkoleniowych w zakresie planowania własnej działalności gospodarczej. Wyniki badań ujawniły, że gotowość do podjęcia działalności gospodarczej jest stymulowana przez wiele czynników oraz, że studenci mają niedostateczną wiedzę w zakresie prowadzenia własnej działalności gospodarczej, zatem dostarczenie im odpowiednich kwalifikacji w tym względzie powinno skutkować wzrostem intencji przedsiębiorczych.

\begin{abstract}
The purpose of the research presented in this article is to learn about students' entrepreneurial predispositions and willingness to run a business, the barriers to entrepreneurship and the factors that encourage undertaking business activity. The article is based on the results of own research carried out among university students aged 19-25. The research was carried out among 540 students in Wielkopolska region. Criteria taken into consideration focused on gender and place of residence of respondents. Survey questions concerned entrepreneurial predispositions, available knowledge on starting the business activities, barriers and factors discouraging business undertakings and the forms of supporting entrepreneurship expected by the students. The main, empirical part of the article is based on research carried out by the authors. While the first part reveals students' characteristics, further parts explore entrepreneurial intentions of academic students, as well as factors and barriers that are relevant for the development of their entrepreneurial attitudes and their training needs in order to run their own business. Research results revealed that readiness to undertake economic activity could be stimulated by
\end{abstract}


many factors. The results of the research also indicate deficiencies in students' knowledge on how to run their own business.

Słowa kluczowe: intencje przedsiębiorcze; postawy przedsiębiorcze; przedsiębiorczość; studenci; własny interes

Keywords: entrepreneurship; entrepreneurial attitudes; entrepreneurial intention; university students; own business

Otrzymano: 9 czerwca 2019

Received: 9 June 2019

Zaakceptowano: 22 marca 2020

Accepted: 22 March 2020

Sugerowana cytacja/Suggested citation:

Gano, E., Łuczka, T. (2020). Determinanty intencji przedsiębiorczych studentów. Przedsiębiorczość - Edukacja [Entrepreneurship - Education], 16(1), 31-44. doi: 10.24917/20833296.161.3

\section{Wstęp}

Przedsiębiorczość wyraża się w działalności osób charakteryzujących się dynamicznym reagowaniem na zmiany powstające $\mathrm{w}$ otoczeniu, zdolnością rozpoznawania okazji oraz zdolnością podejmowania ryzyka (Drucker, 1998; Westlund, 2011). Osoba przedsiębiorcza charakteryzuje się kreatywnością i jest zorientowana na innowacje. Cechy takie umożliwiają jej sprawne i skuteczne realizowanie celów oraz pomagają w działaniach związanych z inicjowaniem działalności gospodarczej i zarządzaniem przedsiębiorstwem. Przedsiębiorczość zorientowana na podejmowanie decyzji o zakładaniu własnej firmy jest warunkiem koniecznym, ale niewystarczającym, aby takie działania wystąpiły. Jednakże, nie zawsze osoby z przedsiębiorczym potencjałem mają pragnienie bycia przedsiębiorcą. Kształtowanie postaw przedsiębiorczych w społeczeństwie jest istotnym elementem wpływającym na rozwój gospodarki, ważne jest zatem regularne badanie wpływu różnych czynników na postawy przedsiębiorcze. Tak w teorii, jak i w życiu gospodarczym problematyka kształtowania postaw przedsiębiorczych uznawana jest za interesującą, ważną i wymagającą ciągłej obserwacji i badań. Celem niniejszego artykułu jest prezentacja intencji studentów w stosunku do zakładania własnej firmy, czynników motywujących i barier wpływających na ich decyzje oraz potrzeb szkoleniowych studentów w zakresie planowania własnej działalności gospodarczej. W związku z tym poszukuje się odpowiedzi na następujące pytania badawcze: po pierwsze, jakie są intencje przedsiębiorcze studentów, po drugie, jakie są motywatory ich intencji przedsiębiorczych, po trzecie, jakie bariery działań przedsiębiorczych wskazują studenci.

\section{Intencje przedsiębiorcze}

Intencja przedsiębiorcza jest definiowana jako „odbierane przez samego siebie przekonanie o zamierzeniu stworzenia przedsięwzięcia gospodarczego i świadomym planowaniu stworzenia tego procesu w przyszłości” (Thompson, 2009: 676). Proces kształtowania się intencji przedsiębiorczej jest uzależniony od wielu czynników. Istotne są z tego punktu widzenia cechy osobowościowe i zdolności, jak również otoczenie, w którym funkcjonuje człowiek, czynniki sytuacyjne, standardy społeczne i kulturowe oraz wychowanie. 
W literaturze przedmiotu podejmowane są próby klasyfikacji czynników inicjujących powstawanie i rozwój przedsiębiorczości oraz cech, które charakteryzują osobę przedsiębiorczą. Postawa przedsiębiorcza to cechy osobowości opisujące konkretne zachowania ludzkie i działania ukierunkowane na innowacyjność, zdolność do akceptowania zmian, możliwość skorzystania z okazji i podejmowania ryzyka. Należy jednak podkreślić, że przedsiębiorczy potencjał jednostki nie jest jednoznaczny z chęcią bycia przedsiębiorcą (Athayde, 2009). Zgodnie z teorią Ajzena (1991), intencje w swojej najprostszej postaci przewidują zachowanie, podczas gdy określone postawy przewidują zamiar. Przedsiębiorczość zorientowana na podejmowanie działalności gospodarczej jest warunkiem koniecznym, ale niewystarczającym, aby takie działania wystąpiły. Interesującą propozycję klasyfikacji determinant przedsiębiorczości zaproponowali M. Peters, C. Sigl i A. Strobl (2007), którzy stworzyli ją do badań nad przedsiębiorczością akademicką. Autorzy ci wykazali, że dwie znaczące cechy przedsiębiorcy, takie jak chęć bycia samodzielnym oraz gotowość bycia przedsiębiorczym, są wypadkową wewnętrznych i zewnętrznych uwarunkowań (rycina 1).

Rycina 1. Cechy i czynniki zamiaru bycia samodzielnym oraz intencji przedsiębiorczych studentów

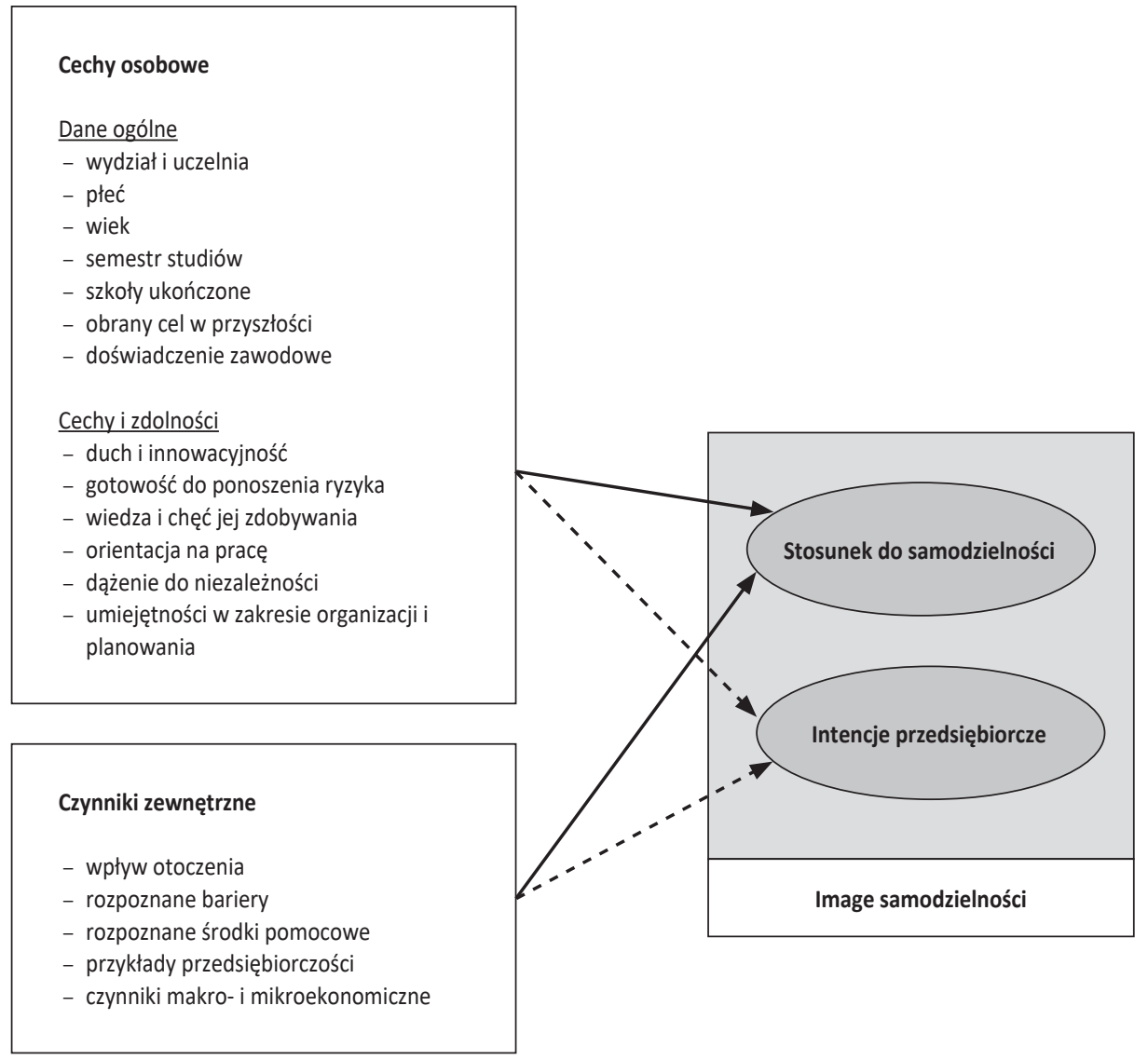

Źródło: Peters, Sigl, Strobl (2007: 298) 
Determinanty intencji przedsiębiorczych studentów w świetle badań własnych

\section{Metoda badań}

Badania zostały przeprowadzone $\mathrm{z}$ zastosowaniem anonimowej ankiety. Starano się ustalić postawy przedsiębiorcze studentów przez określenie przez nich wybranych cech wewnętrznych i dokonanie samooceny w badanym obszarze. Zbadano plany studentów dotyczące utworzenia własnej firmy, opinie na temat ograniczenia rozwoju przedsiębiorczości i motywatorów podejmowania decyzji o założeniu własnego przedsiębiorstwa, jak również oczekiwanych przez studentów form wspomagania przedsiębiorczości. Ankietę przeprowadzono w styczniu 2017 r. w sposób audytoryjny w grupie 534 osób na terenie uczelni wyższych województwa wielkopolskiego. Dobór próby miał charakter kwotowy. Kobiety stanowiły 59,6\%, natomiast mężczyźni - 40,4\% respondentów. Badanie przeprowadzono, przyjmując jako kryterium miejsce zamieszkania respondentów według następującego podziału: wieś (43,6\% badanych), miasto do 4,9 tys. mieszkańców (9,2\% badanych), miasto 5-49 tys. mieszkańców (21,4\% badanych), miasto powyżej 49 tys. mieszkańców (25,8\% badanych).

\section{Cechy przedsiębiorcze studentów w subiektywnej ocenie}

Przez określenie odpowiednich cech i dokonanie samooceny w badanym obszarze starano się ustalić postawy przedsiębiorcze studentów zgodnie ze stwierdzeniem, że określone postawy przewidują zamiar (Ajzen, 1991). Zgodnie z uzyskanymi wynikami badań, ambicją i uporem w dążeniu do celu cechuje się $21,7 \%$ badanych. Niespełna jedna piąta badanych $(18,7 \%)$ uważa się za osoby zaradne, przebojowe, z inicjatywą. Analiza wyników badań ujawniła, że jedna trzecia badanych studentów (35,2\%) postrzega siebie jako osoby elastyczne, dostosowujące się do okoliczności, przy czym większą elastycznością cechują się mężczyźni (39,3\%) niż kobiety (32,3\%) (rycina 2). Bogatą wyobraźnią i różnorodnością pomysłów cechuje się $26 \%$ badanych, jednakże atrybut ten wskazał większy o 7,5 pp odsetek mężczyzn.

Analizując cechę elastyczności pod względem miejsca zamieszkania, najbardziej dostosowują się do okoliczności mieszkańcy miast 5-49 tys. mieszkańców, natomiast najsłabiej obywatele małych miast do 4,9 tys. mieszkańców, którzy jednocześnie najsłabiej oceniali również swoją zaradność.

Badanych studentów cechuje łatwość dostrzegania sprzyjających okoliczności i zdolność korzystania z nadarzającej się okazji $(66,7 \%)$. Deklarują oni, że radzą sobie z sytuacjami niepewnymi (56,7\%), niemniej jednak $17,8 \%$ z nich raczej nie wykorzystuje w pełni swoich możliwości - dotyczy to w większym stopniu mężczyzn $(54,7 \%)$ niż kobiet $(45,3 \%)$.

Samoświadomość bycia przedsiębiorczym cechuje $41 \%$ studentów, jednakże 23,8\% nie uważa się za osoby przedsiębiorcze - $66,9 \%$ tej grupy to kobiety - natomiast więcej niż co trzeci student nie potrafi tego określić (rycina 3).

Postrzeganie siebie jako osoby przedsiębiorczej jest istotnie zróżnicowane ze względu na płeć: połowa studentów uważa się za osobę przedsiębiorczą, natomiast tak o sobie sądzi tylko 34,4\% badanych studentek. Mniejsze poczucie pewności siebie w kwestii bycia przedsiębiorczym przez kobiety ujawniono już niejednokrotnie (por. Harris, 
Rycina 2. Samoocena kompetencji przedsiębiorczych badanych studentów według kryterium płci (w \%)

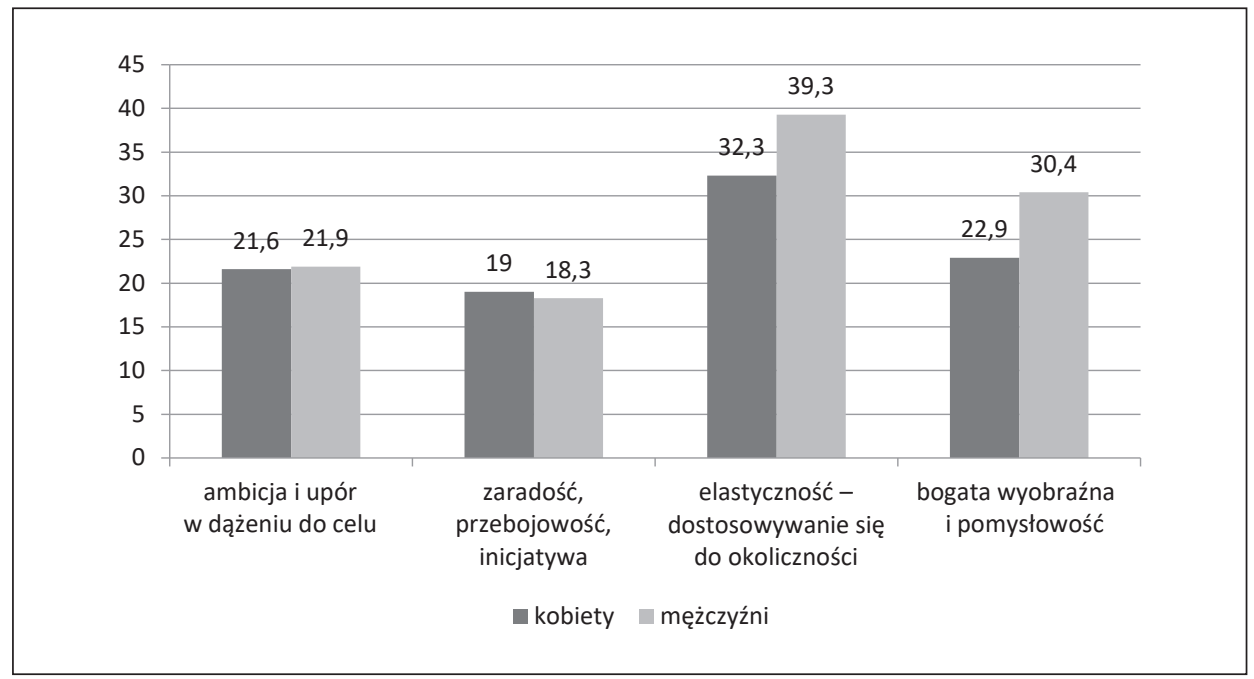

Źródło: badania własne

Rycina 3. Samoświadomość bycia przedsiębiorczym w opinii badanych studentów (w \%)

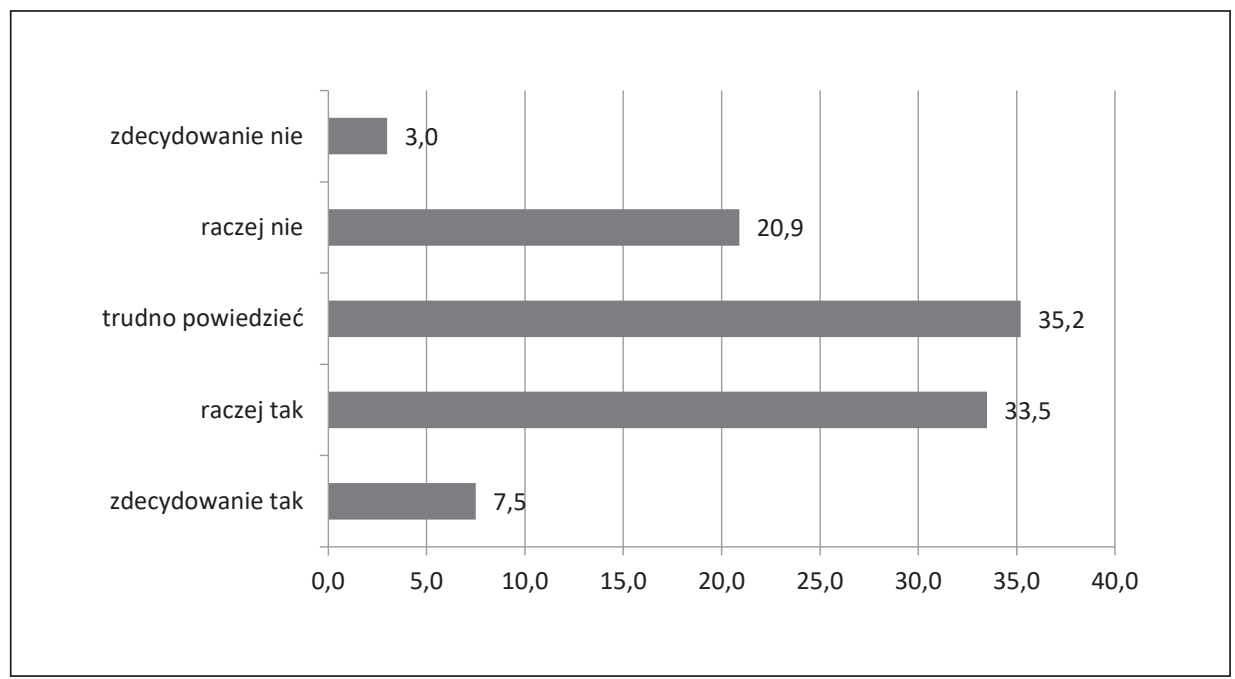

Źródło: opracowanie własne

Gibson, 2008; Łuczka, Rembiasz, 2016), niemniej jednak można zaobserwować zmieniającą się tendencję i coraz większą aktywność kobiet w kwestii przedsiębiorczości. Najbardziej przedsiębiorczy czują się mieszkańcy wsi $(43,8 \%)$ i miast powyżej 49 tys. mieszkańców $(43,4 \%)$, natomiast najsłabiej - mieszkańcy małych miast do 4,9 tys. mieszkańców - mieszkający tam respondenci najczęściej wykazywali, że raczej nie lub zdecydowanie nie są przedsiębiorczy $(36,7 \%)$. 
Planowanie własnej działalności gospodarczej

Wiedza jest ważnym zasobem potrzebnym do osiągnięcia oczekiwanego sukcesu przez potencjalnego przedsiębiorcę. Odpowiednie umiejętności niezbędne do prowadzenia działalności gospodarczej stanowią kluczowy element w procesie podejmowania decyzji o uruchamianiu własnego przedsiębiorstwa. Zgodnie z wynikami badań, studenci słabo oceniają swoją wiedzę pozwalającą na prowadzenie firmy. Zaledwie 20,2\% badanych twierdzi, że posiada niezbędne kompetencje w tym zakresie, natomiast 43,3\% twierdzi odwrotnie. Więcej niż co trzeci badany student nie potrafi sprecyzować poziomu swoich umiejętności w tym obszarze (rycina 4).

Analiza wyników zależności między posiadaną wiedzą a płcią studentów wskazuje na to, że kobiety oceniają swoje przygotowanie o 13,1\% niżej od mężczyzn. Z kolei wyniki zależności pomiędzy posiadaną wiedzą a miejscem zamieszkania pokazują, że najlepiej swoje kompetencje w tym zakresie oceniają mieszkańcy wsi, a najsłabiej - mieszkańcy małych miast do 4,9 tys. mieszkańców.

Istotną kwestią z punktu widzenia prowadzonych badań jest potencjalna gotowość do utworzenia własnej firmy. Analiza uzyskanych danych pozwala określić intencje przedsiębiorcze studentów. Z badań wynika, że 11,8\% respondentów zdecydowanie planuje założenie własnej firmy, 20,2\% raczej planuje swoją działalność gospodarczą, 42,1\% nie potrafi sprecyzować swoich planów w tym zakresie, natomiast więcej niż co czwarty badany deklaruje, że nie planuje otwierać własnego przedsiębiorstwa. Spośród studentów deklarujących chęć uruchomienia własnego przedsiębiorstwa 10\% chce łączyć prowadzenie firmy z kontynuowaniem nauki, 29\% planuje działalność gospodarczą po ukończeniu studiów pierwszego stopnia, 34\% - po ukończeniu studiów magisterskich. Prawie co trzeci badany nie potrafi określić terminu uruchomienia własnej firmy.

Rycina 4. Poziom wiedzy i umiejętności do prowadzenia działalności gospodarczej w opinii badanych studentów (w \%)

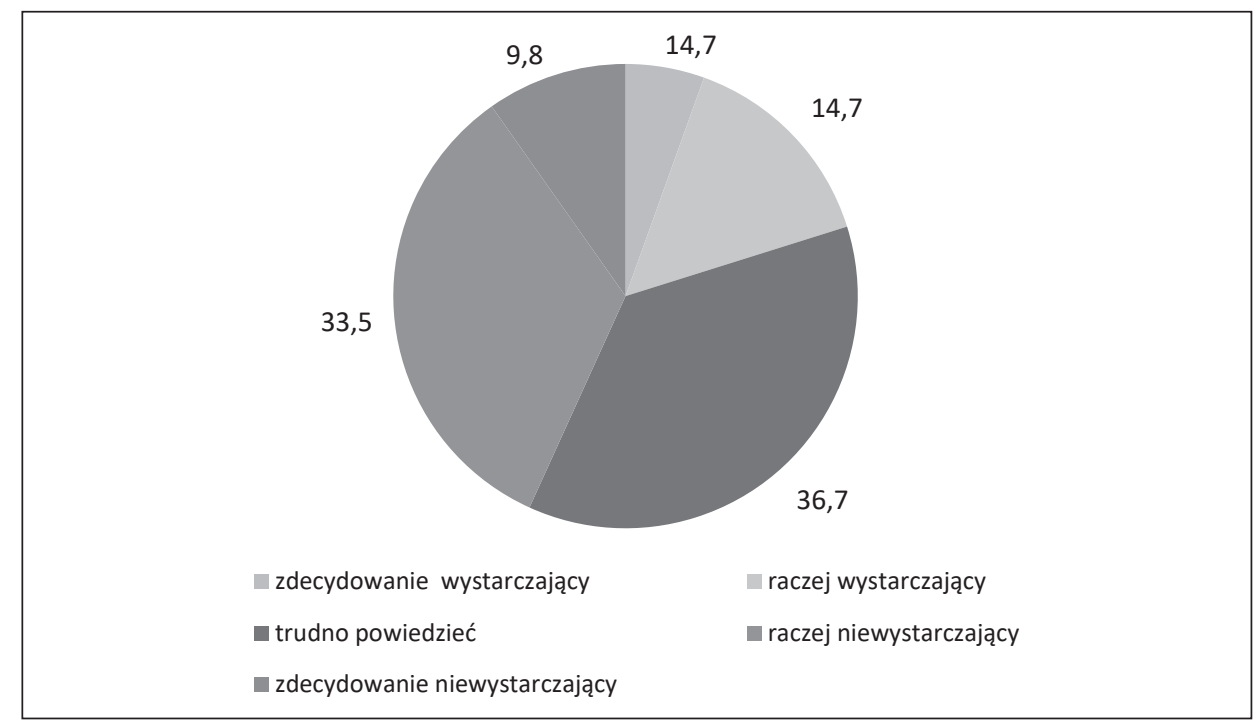

Źródło: opracowanie własne 
Rycina 5. Zależność chęci otwierania własnej firmy od poziomu wiedzy i umiejętności do prowadzenia działalności gospodarczej w opinii badanych studentów (w \%)

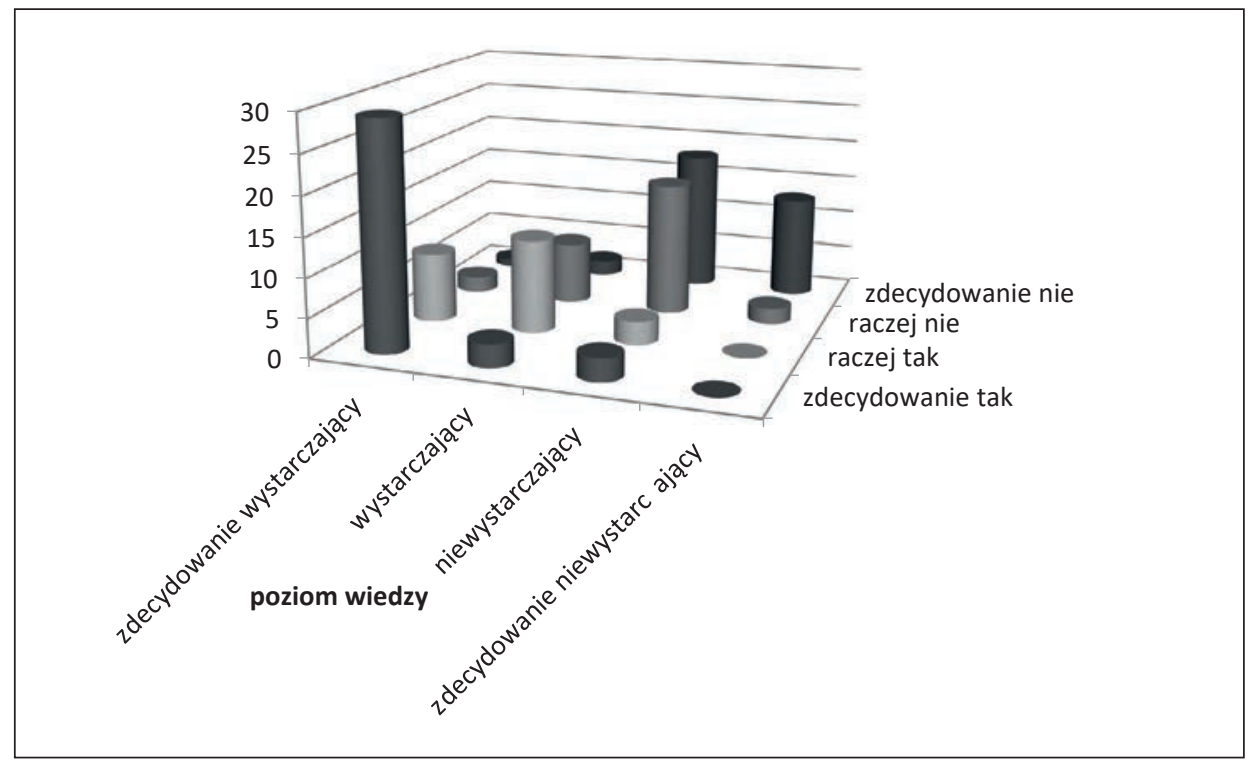

Źródło: opracowanie własne

Wyniki badań ujawniły dużą zależność pomiędzy posiadaną wiedzą i umiejętnościami pozwalającymi na prowadzenie własnej firmy a zamiarem założenia własnej firmy (rycina 5). Okazuje się, że spośród osób, które wysoko oceniają swoje kompetencje w tym zakresie, zaledwie 29\% planuje podjąć działalność gospodarczą. Można również wskazać wyraźną tendencję: im gorzej studenci oceniają swoją wiedzę, tym mniej są zainteresowani zakładaniem własnej firmy.

W literaturze przedmiotu często wskazuje się, że doświadczenie przedsiębiorczości rodzinnej ma wpływ na intencje przedsiębiorcze (Saeed, Muffatto, Yousafzai, 2014; Wach, 2015), stąd w tym względzie istotny jest przykład przedsiębiorczych postaw rodziców, rodziny i przyjaciół. Zdecydowana większość (71,2\%) badanych ma bezpośredni kontakt z osobami prowadzącymi własne firmy. Zbadano również zależność pomiędzy kontaktem badanych studentów z przedsiębiorcami a chęcią zakładania własnej firmy. Analiza danych wskazuje na występowanie wyraźnych korelacji tych dwóch zależnych. Występuje zdecydowana różnica pomiędzy osobami, które mają kontakt z przedsiębiorcami, a badanymi, którzy go nie posiadają. Zdecydowanie większy odsetek badanych, którzy mają w swoim otoczeniu przedsiębiorcę, planuje w przyszłości otwarcie własnej firmy $(31,2 \%)$, podczas gdy $21,3 \%$ nie tego przewiduje.

\section{Motywatory podejmowania decyzji o założeniu własnego przedsiębiorstwa}

Podjęciu decyzji o uruchomieniu działalności gospodarczej towarzyszą czynniki motywujące. W ocenie studentów posiadanie własnej firmy zapewnia większe uznanie społeczne niż praca na etacie - twierdzi tak zdecydowana większość respondentów. Ważną rolę $\mathrm{w}$ pobudzaniu intencji przedsiębiorczych odgrywa przykład działań przedsiębiorczych 
w najbliższym otoczeniu badanych studentów. Analiza zależności pomiędzy kontaktem badanych studentów z przedsiębiorcami a chęcią zakładania firmy wykazała, że zdecydowanie większy odsetek badanych, którzy mają w swoim najbliższym otoczeniu przedsiębiorcę, planuje w przyszłości otwarcie firmy. Studenci uważają, że prowadzenie własnej firmy wiąże się z większym ryzykiem niż praca na etacie. Dominującym czynnikiem motywującym założenie działalności gospodarczej przez studentów bez względu na płeć i wielkość miejsca zamieszkania badanych jest chęć uzyskania wysokich dochodów. Należy jednak podkreślić, że mężczyźni (62,9\%) są bardziej zmotywowani w tym zakresie niż kobiety (58,7\%). Drugim dominującym czynnikiem jest możliwość decydowania o sobie w kwestii zatrudnienia. Czynnik ten wskazało 50,2\% badanych; motywuje on w większym stopniu kobiety niż mężczyzn. Pod względem miejsca zamieszkania czynnik ten nieco mniej w porównaniu $\mathrm{z}$ innymi motywuje mieszkańców małych miast do 5 tys. mieszkańców.

Ważnym motywatorem działań przedsiębiorczych dla co trzeciego badanego studenta jest również możliwość rozwoju w interesujących go dziedzinach. Czynnik ten dominuje jako motywator wśród mieszkańców dużych miast powyżej 49 tys. mieszkańców (36,2\%). Istotna jest także możliwość samodzielnego decydowania o wymiarze czasu pracy, co potwierdza wskazanie przez co trzeciego badanego studenta. Ryzyko i chęć jego podejmowania raczej nie są postrzegane przez ankietowanych jako czynnik motywujący (tabela 1).

Tabela 1. Motywatory intencji przedsiębiorczych w opinii badanych studentów (w \%)

\begin{tabular}{|l|c|c|c|c|c|c|}
\hline \multicolumn{1}{|c|}{ Motywator } & Kobiety & Mężczyźni & Wieś & $\begin{array}{c}\text { Miasto } \\
\text { do 4,9 tys. }\end{array}$ & $\begin{array}{c}\text { Miasto } \\
\text { od 5 do } \\
\mathbf{4 9} \text { tys. }\end{array}$ & $\begin{array}{c}\text { Miasto } \\
\text { powyżej } \\
\text { 50 tys. }\end{array}$ \\
\hline $\begin{array}{l}\text { Chęć osiągnięcia } \\
\text { większych dochodów }\end{array}$ & 58,7 & 62,9 & 57,9 & 65,3 & 59,6 & 63,8 \\
\hline $\begin{array}{l}\text { Możliwość } \\
\text { samozatrudnienia - sam } \\
\text { jestem dla siebie szefem }\end{array}$ & 51,3 & 48,7 & 51,1 & 36,7 & 54,4 & 50,0 \\
\hline $\begin{array}{l}\text { Możliwość rozwoju } \\
\text { w interesującej mnie } \\
\text { dziedzinie }\end{array}$ & 29,7 & 32,1 & 28,3 & 28,6 & 29,8 & 36,2 \\
\hline $\begin{array}{l}\text { Samodzielne decydowanie } \\
\text { o wymiarze czasu pracy }\end{array}$ & 23,9 & 25 & 23,6 & 18,4 & 23,7 & 28,3 \\
\hline $\begin{array}{l}\text { Możliwość doboru } \\
\text { pracowników }\end{array}$ & 19,7 & 17,4 & 20,2 & 12,2 & 18,4 & 18,8 \\
\hline $\begin{array}{l}\text { Posiadanie kapitału } \\
\text { finansowego i chęć jego } \\
\text { powiększenia }\end{array}$ & 14,5 & 17,9 & 18,5 & 6,1 & 14,9 & 15,9 \\
\hline Prestiż, status społeczny & 11,6 & 16,1 & 12 & 16,3 & 12,3 & 15,9 \\
\hline $\begin{array}{l}\text { Odwaga w podejmowaniu } \\
\text { decyzji }\end{array}$ & 7,4 & 4,9 & 6,4 & 8,2 & 7,9 & 4,3 \\
\hline Strach przed bezrobociem & 5,8 & 4,9 & 5,6 & 8,2 & 0,9 & 8,0 \\
\hline Tradycje rodzinne & 4,5 & 6,3 & 4,3 & 4,1 & 5,3 & 7,2 \\
\hline $\begin{array}{l}\text { Możliwość podejmowania } \\
\text { ryzyka }\end{array}$ & 3,9 & 8,0 & 5,6 & 6,1 & 2,6 & 8,0 \\
\hline
\end{tabular}

Źródło: opracowanie własne 


\section{Bariery działań przedsiębiorczych}

Skłonność do podejmowania działań przedsiębiorczych oraz potencjał tkwiący w studentach są niejednokrotnie hamowane przez szereg barier i utrudnień. Ograniczenia o dość zróżnicowanej typologii mogą mieć negatywny wpływ na rozwój przedsiębiorczości. Zgodnie z wynikami badań, kluczową barierą w tym zakresie są środki finansowe wskazane przez 51,5\% wszystkich badanych. Studenci wskazywali na wysokie koszty związane z prowadzeniem własnej firmy, jak również na brak środków finansowych potrzebnych do uruchomienia działalności gospodarczej. Istotny problem w opinii badanych stanowią również wysokie ceny najmu powierzchni użytkowej lokali. Kolejną barierę stanowi ryzyko związane z prowadzeniem własnego biznesu - wskazało na nią $37,8 \%$ badanych. Należy podkreślić, że ryzyko wiąże się w określonym stopniu z brakiem odpowiedniej wiedzy, którą jako barierę wskazało $24,5 \%$ respondentów. Stres związany z prowadzeniem firmy oraz strach przed porażką stanowi większe ograniczenie na drodze uruchamiania własnej działalności gospodarczej dla kobiet niż dla mężczyzn (różnica kolejno 9,5 i 13,3). W najmniejszym stopniu stresu obawiają się mieszkańcy dużych miast (12,3\%), natomiast największą, dwukrotnie większą barierę $(25,8 \%)$ stanowi on dla mieszkańców. Duży odsetek badanych studentów $(19,3 \%)$ wskazał jako istotną barierę brak pomysłu na własny biznes. Co czwarty badany $(25,4 \%)$ mieszkający w dużym mieście (powyżej 49 tys.) wskazywał ten czynnik jako utrudniający podjęcie decyzji o założeniu własnej firmy, natomiast dla grupy osób mieszkających w średnich i małych miasteczkach oraz na wsi jest to mniejsza bariera (kolejno: 17,5\%,14,3\%, 17,6\%). Założenie rodziny i wychowywanie dzieci w większym stopniu stanowi barierę dla mężczyzn niż dla kobiet (tabela 2).

Tabela 2. Bariery działań przedsiębiorczych w opinii badanych studentów (w \%)

\begin{tabular}{|l|c|c|c|c|c|c|}
\hline \multicolumn{1}{|c|}{ Bariery } & Kobiety & Mężczyźni & Wieś & $\begin{array}{c}\text { Miasto } \\
\text { do 4,9 } \\
\text { tys. }\end{array}$ & $\begin{array}{c}\text { Miasto } \\
\text { od 5 do } \\
\text { 49 tys. }\end{array}$ & $\begin{array}{c}\text { Miasto } \\
\text { powyżej } \\
\text { 49 tys. }\end{array}$ \\
\hline Finanse & 54,8 & 46,9 & 53,2 & 38,8 & 50,0 & 54,3 \\
\hline Ryzyko & 37,7 & 37,9 & 34,8 & 42,9 & 42,1 & 37,7 \\
\hline Strach przed porażką & 27,1 & 13,8 & 25,8 & 24,5 & 22,8 & 12,3 \\
\hline Brak wiedzy i umiejętności & 24,5 & 24,6 & 25,3 & 12,2 & 21,9 & 29,7 \\
\hline $\begin{array}{l}\text { Stres związany z własną } \\
\text { działalnością }\end{array}$ & 24,2 & 14,7 & 25,8 & 20,4 & 18,4 & 12,3 \\
\hline Brak pomysłu & 17,4 & 21,9 & 17,6 & 14,3 & 17,5 & 25,4 \\
\hline $\begin{array}{l}\text { Założenie rodziny/ } \\
\text { Wychowywanie dzieci }\end{array}$ & 4,8 & 7,1 & 4,3 & 8,2 & 7,0 & 6,5 \\
\hline
\end{tabular}

Źródło: opracowanie własne

\section{Oczekiwane przez studentów formy wspomagania przedsiębiorczości}

W rozwiniętych gospodarkach od początku lat 70. XX w. państwo i inne organizacje gospodarcze formułują politykę na rzecz promowania i rozwoju przedsiębiorczości. Szczególnie intensywnie proces ten odbywa się na poziomie lokalnym i regionalnym, w związku z tym interesujący jest stopień wiedzy studentów na temat instytucji wspierających 
Rycina 6. Wiedza o instytucjach wspierających i promujących przedsiębiorczość w opinii badanych studentów (w \%)

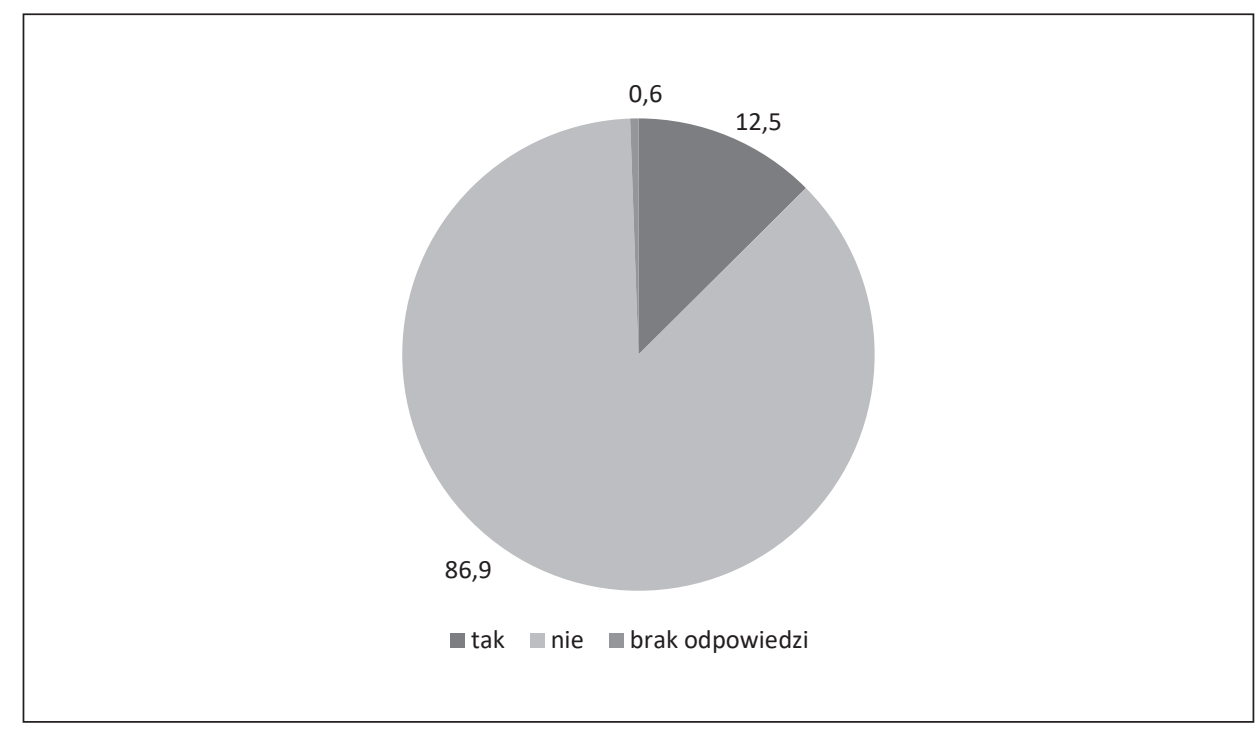

Źródło: badania własne

i promujących przedsiębiorczość. Wyniki przeprowadzonych badań wskazują na to, że respondenci w znacznej większości nie znają takich instytucji - 86,9\% (rycina 6). Spośród 12,5\% osób, które twierdzą, że instytucje wspierające przedsiębiorczość nie są im obce, najwięcej studentów wskazywało na inkubatory przedsiębiorczości, a w drugiej kolejności na urzędy pracy, następnie stowarzyszenia, biura karier działające przy uczelniach oraz banki.

Badaniom poddano również odczucia respondentów dotyczące faktycznych potrzeb w zakresie rozwoju przedsiębiorczości (poproszono studentów o ich wskazanie). Wiedza na ten temat pozwala wskazać, jakie działania powinny zostać przeprowadzone. Wśród nich znalazła się obsługa prawna i księgowa młodych firm, wskazana przez 67,4\% badanych. Drugą ważną grupą okazały się szkolenia (66,5\%), co potwierdza przekonanie o niewystarczającym poziomie wiedzy i umiejętności do prowadzenia własnej firmy. Respondenci wykazali również zainteresowanie pomocą w formie doradztwa dla osób rozpoczynających działalność gospodarczą - tym rodzajem wsparcia bardziej zainteresowane są kobiety $(67,1 \%)$ niż mężczyźni (52,7\%). Studenci w dużym stopni wskazywali, że oczekują od tego typu instytucji bezpośredniej pomocy finansowej w postaci pożyczek czy dotacji 63,9\%. Tylko co trzeci student byłby zainteresowany wsparciem w postaci opieki bardziej doświadczonego przedsiębiorcy - co jest zaskakujące.

Analiza potrzeb szkoleniowych wykazała, że studenci są najbardziej zainteresowani szkoleniami z zakresu procedur zakładania firmy - 69,5\% z nich uważa takie szkolenie za przydatne. Warto podkreślić, że kobiety, które oceniały swoją wiedzę i umiejętności w tym zakresie, częściej od mężczyzn wskazywały na potrzebę szkolenia z tego obszaru (kolejno $77,7 \%$ i 58,0\%). Studenci, którzy wskazywali potrzebę szkolenia z zakresu prawa gospodarczego, stanowili ponad połowę respondentów - 62,7\%. W tym obszarze szkoleniami bardziej zainteresowani są mężczyźni niż kobiety (M: 68,8\%, K: 58,4\%). Również 53,7\% 
badanych uważa za przydatne szkolenie z zakresu pozyskiwania funduszy na uruchomienie własnej firmy. Najmniejszym zainteresowaniem cieszyłoby się szkolenie z prawa z zakresu ochrony środowiska - tylko 4,7\% badanych zaznaczyło taką możliwość (tabela 3).

Tabela 3. Potrzeby szkoleniowe badanych studentów (w \%)

\begin{tabular}{|l|c|}
\hline \multicolumn{1}{|c|}{ Tematyka szkolenia } & Wskazania przydatności \\
\hline Jak założyć firmę (wymogi formalne, pozwolenia/licencje) & 69,5 \\
\hline Prawo gospodarcze (US, ZUS, kodeks pracy) & 62,7 \\
\hline Pozyskiwanie funduszy na uruchomienie firmy & 53,7 \\
\hline Księgowość & 44,4 \\
\hline Tworzenie strategii firmy & 42,3 \\
\hline Marketing (analiza potrzeb klientów, reklama, sprzedaż) & 34,5 \\
\hline Techniki opracowywania biznesplanów & 28,5 \\
\hline Nauka obcego języka & 23,2 \\
\hline Zarządzanie zespołem & 21,5 \\
\hline Identyfikacja atrakcyjnych pomysłów biznesowych & 21,3 \\
\hline $\begin{array}{l}\text { Komunikacja w biznesie/Jak być liderem zatrudnienia - prawo } \\
\text { pracy }\end{array}$ & 20,4 \\
\hline $\begin{array}{l}\text { Problematyka ochrony własności przemysłowej (patenty, znaki } \\
\text { towarowe, prawo autorskie) }\end{array}$ & 17,0 \\
\hline Negocjacje & 16,1 \\
\hline Wykorzystanie internetu w biznesie & 9,0 \\
\hline Prawo ochrony środowiska & 4,7 \\
\hline Nie potrzebuję żadnych szkoleń & 1,1 \\
\hline
\end{tabular}

Źródło: badania własne

\section{Zakończenie}

Wyniki badań przeprowadzonych w zakresie determinant intencji przedsiębiorczych studentów są zróżnicowane ze względu na wybrane kryteria, takie jak płeć oraz miejsce zamieszkania. Badani studenci wykazują się cechami przedsiębiorczymi, postrzegają siebie jako osoby elastyczne, dostosowujące się do okoliczności, pomysłowe, ambitne oraz dostrzegające sprzyjające okoliczności. Niemniej jednak cechy te wskazywali częściej mężczyźni niż kobiety. Najsłabiej w tym zakresie oceniają się mieszkańcy małych miast. Z punktu widzenia prowadzonych badań ważna była samoświadomość bycia osobą przedsiębiorczą. Zgodnie z uzyskanymi wynikami postrzeganie to jest istotnie zróżnicowane ze względu na płeć i jest zdecydowanie słabsze wśród kobiet. Respondenci bardzo nisko oceniają swoją wiedzę i umiejętności z zakresu prowadzenia własnej działalności gospodarczej. Analiza zależności pomiędzy posiadaną wiedzą a zamiarem założenia własnej firmy wykazała, że im gorzej studenci oceniają swoje kompetencje, tym w mniejszym stopniu zainteresowani są zakładaniem własnego przedsiębiorstwa. W związku z niewystarczającym poziomem wiedzy posiadanym przez studentów jedną z najbardziej oczekiwanych form wsparcia przez instytucje wspierające i promujące działania przedsiębiorcze są dla badanych różnego rodzaju szkolenia. Badania wykazały jednak, że studenci mają niewielką wiedzę na temat tego typu organizacji, co może świadczyć o tym, że taka 
sytuacja wymaga od tego typu instytucji opracowania koncepcji i organizacji kampanii promocyjnych kierowanych do uczelni.

Podstawowym czynnikiem stymulującym podejmowanie decyzji o własnej działalności gospodarczej bez względu na jakiekolwiek kryteria jest chęć uzyskania wysokich dochodów. Ważnymi dla studentów stymulatorami podejmowania decyzji o założeniu firmy jest także możliwość samozatrudnienia oraz wpływ na organizację czasu i styl życia. Istotna dla badanych respondentów jest również możliwość realizowania się w interesującej dziedzinie. W opinii studentów posiadanie własnej firmy zapewnia większe uznanie społeczne niż praca na etacie - co również stanowi motywator do jej posiadania. Mniejsze znaczenie zaczynają odgrywać tradycyjne motywy budowy firmy, takie jak: podejmowanie ryzyka, czy obawa przed bezrobociem - które obecnie raczej stanowią barierę, a nie motywator.

Intencjom przedsiębiorczym badanych respondentów towarzyszy wiele barier i ograniczeń, zróżnicowanych w różnym zakresie. Największą barierę stanowi brak środków finansowych potrzebnych do uruchomienia i prowadzenia własnej firmy. Wśród oczekiwanych przez studentów form wspomagania przedsiębiorczości znalazły się m.in. szkolenia z zakresu pozyskiwania środków finansowych potrzebnych do uruchomienia i prowadzenia własnej działalności, a zatem można stwierdzić, że dostarczenie im odpowiedniej wiedzy w tym temacie powinno skutkować wzrostem intencji przedsiębiorczych. Znacząca barierę stanowi ryzyko związane z prowadzeniem przedsiębiorstwa. Stres związany z prowadzeniami własnego biznesu i obawa porażki szczególnie stanowią przeszkodę w działaniach przedsiębiorczych kobiet oraz mieszkańców wsi. Ze względu na ten fakt można stwierdzić, że warto podjąć działania wspierające przedsiębiorczość w tych obszarach. Wbrew wszelkim stereotypom kobiety rzadziej niż mężczyźni wskazywały wychowywanie dzieci jako barierę założenia własnej firmy. Istotną barierą jest również brak pomysłu na własny biznes wskazywany częściej przez mężczyzn niż przez kobiety oraz wśród osób z dużych miast powyżej 49 tys. mieszkańców.

Ważnym czynnikiem jest konstruowanie odpowiedniej polityki na rzecz pobudzania i rozwoju przedsiębiorczości. Wnikliwa analiza determinant intencji przedsiębiorczych studentów wymaga dalszych badań. W najbliższych latach warto zwrócić uwagę na zmianę trendów, które mogą pojawić się w związku ze wzmocnieniem edukacji w zakresie przedsiębiorczości.

Literatura

References

Ajzen, I. (1991). Theory of planned behavior. Organizational Behavior and Human Decision Processes, $50,179-211$.

Athayde, R. (2009). Measuring Enterprise Potential in Young People. Entrepreneurship. Theory and Practice, $1042-2587$.

Banerski, G., Gryzik, A., Matusiak, K.B., Marzewska, M., Stawasz, E. (2009). Przedsiębiorczość akademicka. Raport z badania. Warszawa: PARP.

Drucker, P.F. (1998). Praktyka zarzadzania. Kraków: Czytelnik - Nowoczesność - Akademia Ekonomiczna w Krakowie.

Harris, M.L., Gibson, S.G. (2008). Examining the entrepreneurial attitudes of US business students. Education + Training, 50(7), 568-581. doi: https://doi.org/10.1108/00400910810909036

Hudson, J.W. (1993). Intellectual Capital. How to build it, Enhance it, Use it. New York: John Wiley\&Sons. 
Łuczka, T., Rembiasz, M. (2016). Badanie postaw przedsiębiorczych studentów - wybrane aspekty teoretyczne i empiryczne. Horyzonty Wychowania, 15(34), 27-47. doi: https://doi.org/10.17399/ HW.2016.153402

Peters, M., Sigl, C., Strobl, A. (2007). Die Einstellung zum Unternehmertum aus Sicht zukünftiger Universitätsabsolventen. Zeitschrift für KMU und Entrepreneurship, 4, 291-308.

Poznańska, K. (2014). Przedsiębiorczość akademicka - cechy i znaczenie w gospodarce światowej i polskiej. W: T. Kraśnicka (red.), Innowacyjność wspótczesnych organizacji. Kierunki i wyniki badań. Część II. Katowice: Uniwersytet Ekonomiczny w Katowicach, 164-172.

Saeed, S., Muffatto, M., Yousafzai, Sh.Y. (2014). Exploring intergenerational influence on entrepreneurial intention: the mediating role of perceived desirability and perceived feasibility. International Journal of Entrepreneurship \& Innovation Management, 18(2/3), 134-153.

Thompson, E.R. (2009). Individual Entrepreneurial Intent: Construct Clarification and Development of an Internationally Reliable Metric. Entrepreneurship Theory \& Practice, 3(33), 669-694.

Wach, K. (2015). Środowisko biznesu rodzinnego jako stymulanta intencji przedsiębiorczych młodzieży akademickiej. Przedsiębiorczości i Zarzadzanie, XVI(7/III), 25-40.

Westlund, H. (2011). Multidimensional Entrepreneurship: Theoretical Considerations and Swedish Empirics. Regional Science Policy \& Practice, 3(3), 2-3.

Ewa Gano, mgr inż., absolwentka Wydziału Informatyki i Zarządzania Politechniki Poznańskiej, obecnie doktorantka na Wydziale Inżynierii Zarządzania, Katedra Przedsiębiorczości i Komunikacji w Biznesie tej samej uczelni. Ukończyła studia podyplomowe na Wydziale Matematyki Uniwersytetu im. Adama Mickiewicza w Poznaniu oraz studia podyplomowe z zakresu zarządzania oświatą również na UAM. Zainteresowania badawcze autorki koncentrują się przedsiębiorczości MŚP oraz postawach przedsiębiorczych dzieci, młodzieży i studentów.

Ewa Gano, MSc, graduate of the Faculty of Computer Science and Management at the Poznan University of Technology, currently a PhD student at the Faculty of Management Engineering, Department of Entrepreneurship and Business Communication at the same university. She has completed post-graduate studies in Mathematics at the Faculty of Mathematics of the Adam Mickiewicz University in Poznan and post-graduate studies in Education Management also at UAM. The author's research interests focus on SME entrepreneurship and entrepreneurial attitudes of children, youth and students.

ORCID: https://orcid.org/0000-0003-3132-9338

\section{Adres/Address:}

Politechnika Poznańska

Wydział Inżynierii Zarządzania

Katedra Przedsiębiorczości i Komunikacji w Biznesie

ul. Strzelecka 11

60-965 Poznań, Polska

e-mail: ewa.gano@doctorate.put.poznan.pl

Teresa Łuczka, prof. dr hab. Politechnika Poznańska Wydział Inżynierii Zarządzania kierownik Katedry Przedsiębiorczości i Komunikacji w Biznesie; kierownik Studiów Doktoranckich. Autorka wielu publikacji naukowych dotyczących problemów funkcjonowania małych i średnich przedsiębiorstw.

Teresa Łuczka, professor, DSc, Poznan University of Technology Faculty of Management Engineering, Head of the Chair of Entrepreneurship and Business Communication; Head of Doctoral Studies. Author of numerous publications dealing with SMEs.

ORCID: https://orcid.org/0000-0002-1149-4988 
Adres/Address:

Politechnika Poznańska

Wydział Inżynierii Zarządzania

Katedra Przedsiębiorczości i Komunikacji w Biznesie

ul. Strzelecka 11

60-965 Poznań, Polska

e-mail: teresa.luczka@put.poznan.pl 